\title{
Studentenes erfaringer fra deltakelse i en digital læringsressurs om tverrprofesjonelt samarbeid
}

\author{
Rigmor Furu
}

Fremtidens helsearbeidere trenger samhandlingskompetanse for å imøtekomme en stadig aldrende befolkning med sammensatte og komplekse helseutfordringer i en helse- og velferdstjeneste med behov for å styrke samarbeid og koordinering. Dette kapittelet handler om den digitale læringsressursen Inter-Dig, som ble utviklet for at helsefagstudenter skulle lære tverrprofesjonelt samarbeid. 55 studenter fra ti helsefaglige studieprogram deltok i utprøvingen ved å samarbeide i digitale tverrprofesjonelle grupper med videocaser som utgangspunkt for læring. Kapittelet tar utgangspunkt i studentenes tilbakemeldinger fra evalueringen og diskuterer muligheter og utfordringer ved å samarbeide på en digital arena, uten å møtes fysisk.

\section{Innledning}

Dette kapittelet handler om studenters erfaringer med å lære tverrprofesjonelt samarbeid på en digital arena, gjennom deltakelse i læringsressursen Inter-Dig. Helsefagstudenter ved UiT Norges arktiske universitet lærer tverrprofesjonelt samarbeid (TPS) gjennom sine grunnutdanninger. Gjennom studiet legges det til rette for tverrprofesjonelle læringsaktiviteter underveis, både i teori- og praksisundervisningen. Tverrprofesjonell samarbeidslæring kan forstås som en læringssituasjon der deltakerne både tilegner seg og lærer fra seg kompetanse 
samtidig (Hauksdottir \& Iversen, 2020). Samarbeidslæringen utøves i komplekse situasjoner som krever nøye planlegging og pedagogisk tilrettelegging, utprøving, vurdering og evaluering. Et viktig mål med Inter-Dig var å tilby studentene en digital og fleksibel læringsressurs som kunne gjennomføres som et supplement underveis i studieløpet, og bidra til å styrke tverrprofesjonell samhandlingskompetanse på ulike nivå i utdannings- og læringsprosessen. Den digitale læringsressursen ble utviklet i læringsplattformen Canvas, der samarbeidsverktøy som diskusjonsforum og samskriving ble benyttet. Gjennom Inter-Dig ble det skapt en ny digital samarbeidsarena på tvers av profesjoner og nivå i helsefagutdanningene. Målgruppen for Inter-Dig var studenter fra alle helsevitenskapelige utdanninger ved UiT, men i selve utprøvingen deltok studenter fra seks ulike studieprogram. Dette kapittelet bør leses sammen med kapittelet «Pedagogiske betraktninger rundt utvikling av en digital læringsressurs».

I helse-, sosial- og velferdssektoren er det behov for mer koordinerte og sammenhengende tjenester for å kunne møte pasientenes behov (Helse- og sosialdepartementet, 2009). Dagens befolkning lever lenger, og mange lever med kroniske sykdommer og sammensatte og komplekse helseutfordringer. Mangelen på en helhetlig tilnærming til pasientforløp er et problem for den enkelte pasient ved at de ikke mottar tjenester som er godt nok koordinerte. Dette stiller krav til et helsevesen og helsepersonell som har samhandlingskompetanse, og som kan samarbeide på tvers av fag, nivå og sektorer. Kunnskapsdepartementet (2017) har utarbeidet forskrift om felles innhold for helse- og sosialfagutdanningene (RETHOS) med til sammen 12 felles læringsutbyttebeskrivelser. Det fjerde felles læringsutbyttet omhandler tverrprofesjonell samarbeidslæring. Etter fullført helse- og sosialfagutdanning skal kandidaten «kunne samhandle både tverrfaglig, tverrprofesjonelt, tverrsektorielt og på tvers av virksomheter og nivåer, og initiere slik samhandling». Jill Thistlethwaite (2012) sier at tverrprofesjonelle samarbeidsferdigheter forstås som kommunikasjon, samarbeid, teamarbeid, roller og ansvar, etikk og verdier, læring og refleksjon.

Studenten skal også i løpet av studiet ha oppnådd en minstestandard av sluttkompetanse som omhandler felles læringsutbytte nr. 12: «ha digital kompetanse og kan bistå utviklingen av og bruke egnet teknologi både på individ- og systemnivå» (Kunnskapsdepartementet, 2017). Digitale ferdigheter er å innhente informasjon, være kreativ og skapende med digitale ressurser, samhandle med andre i digitale omgivelser, ha kunnskap om digital sikkerhet 
og utøve digital dømmekraft (Utdanningsdirektoratet, 2016). Digital kompetanse etter endt helsefagutdanning er en viktig kompetanse å ha for å være forberedt til arbeidsoppgaver og arbeidsformer i framtidens helse- og velferdstjenester.

Ifølge Stortingsmeldingsmeldingen Kultur for kvalitet (Meld. St. 16, 2016-2017) og Strategi ved Det helsevitenskapelige fakultet ved UiT Norges arktiske universitet (UiT, 2018-2022) skal det legges til rette for mer fleksible og nettstøttede undervisningsformer, nye pedagogiske virkemidler og studentaktive undervisnings- og læringsformer, og der det er formålstjenlig, skal bruken av læringsfremmende teknologi økes. Inter-Dig er en digital læringsressurs som er utviklet i tråd med disse overordnede føringene.

\section{Tverrprofesjonell samarbeidslæring}

Interprofessional learning (IPL) defineres slik: "When students from two or more professions learn about, from and with each other to enable effective collaboration and improve health outcomes» (WHO, 2010, s. 10). Det helsevitenskapelige fakultet ved UiT Norges arktiske universitet definerer tverrprofesjonell samarbeidslæring (TPS) slik: «Den prosessen der studenter fra to eller flere studieprogrammer lærer av, med og om hverandre gjennom studieforløpene med stigende kompleksitet og praksisnærhet, med mål om å oppnå tverrprofesjonell samhandlingskompetanse.» Thistlethwaite (2012) bebuder at det ikke er nok å bringe de ulike profesjonene sammen, om dette foregår i et klasserom, i praksis eller online. Det må være minst to personer i interaksjonen, og teambasert samarbeid krever kommunikasjon og forståelse av roller og ansvar for å oppnå optimal pleie, omsorg og behandling av pasienten. Ferdigheter i teamarbeid innebærer å kunne lede, koordinere, lære nye roller og sikre at alle er med i samarbeidet. Samarbeid kan også oppstå i andre former for nettverk og på tvers av sektorer og kan medføre endringer i både medlemskap og ledelse. 


\section{Metodisk tilnærming}

Som prosjektleder for Inter-Dig har jeg sammen med prosjektgruppa vært tett på prosessen gjennom planlegging, utvikling, utprøving og evaluering av læringsressursen. Evalueringsskjemaet ble validert og inneholdt 38 spørsmål i nettskjema (nettskjema.uio.no). Spørsmålene var en blanding av åpne og lukkede spørsmål. De fleste spørsmålene var åpne, og disse genererte en stor mengde datamateriale. Evalueringsspørsmålene ble inndelt i tre ulike hovedområder: a) faglig innhold, b) teknologi og pedagogiske verktøy og c) organisering og gjennomføring.

Til sammen deltok 55 studenter i piloteringen av Inter-Dig, fra ti ulike helsefaglige studieprogram: sykepleie, fysioterapi, ergoterapi, medisin, tannlege, tannpleie, psykologi, farmasi, klinisk ernæringsfysiologi og vernepleie. 52 av 55 studenter svarte på evalueringen. Evalueringen ble anonymisert slik at det verken var mulig å gjenkjenne navn og/eller tilhørighet til studieprogram. Alle studentene som deltok i piloteringen av Inter-Dig, fikk tilsendt et skriftlig samtykkeskjema som de skrev under. Studentene er blitt informert og har bekreftet at datamateriale og analysene blir presentert og offentliggjort. Norsk Senter for Forskningsdata (NSD) er kontaktet med tilbakemelding om at prosjektet ikke er meldepliktig.

Analyseprosessen ble utført etter prinsipper for kvalitativ innholdsanalyse (Graneheim \& Lundman, 2004; Kvale, 2001). Jeg startet med gjennomlesning av hele teksten i evalueringen for å få oversikt og danne meg et helhetsinntrykk. Deretter ble dataene organisert etter hovedspørsmålene i evalueringen, som var faglig innhold, teknologi og pedagogiske verktøy, organisering og gjennomføring. Jeg utførte ny gjennomlesning av tekstene der jeg trakk ut meningsfulle utsagn og sitater av datamaterialet. Meningsfortetting ble utført gjennom fortetting og reduksjon av tekstene uten mine egne fortolkninger. Disse fellestrekkene ble delt inn i kategorier, som videre ble analysert og identifisert til følgende tema: læringsprosessen, digitalt samarbeid, bevisstgjøring, refleksjon, kunnskapsutvikling, struktur og fleksibilitet. 


\section{Resultater}

Resultatene fra evalueringen presenteres fortløpende gjennom diskusjonsdelen. De ulike temaene som framkom etter analysen, vil jeg trekke inn i de tre hoveddelene av diskusjonen; dette være seg i forhold til oppnådd læringsutbytte, digitalt samarbeid og organisering og gjennomføring.

\section{Diskusjon}

Hvilke erfaringer har studentene fra å gjennomføre læringsressursen InterDig, og hva kan en lære av deres tilbakemeldinger? Med utgangspunkt i studentenes erfaringer, relevant teori og egne refleksjoner vil jeg diskutere hva som kan bidra til å styrke læringsressursens kvalitet. Diskusjonen deles inn i tre hoveddeler:

1. Hva lærte studentene om tverrprofesjonelt samarbeid på en digital arena?

2. Hvordan samarbeidet studentene tverrprofesjonelt ved hjelp av digitale verktøy?

3. Hvordan ble Inter-Dig organisert og gjennomført, og hva er forbedringspotensialet?

Hva lærte studentene om tverrprofesjonelt samarbeid på en digital arena?

Studentene gir meget høyt score på oppnådd læringsutbytte om tverrprofesjonelt samarbeid og sier at videocase er et godt pedagogisk verktøy for å lære tverrprofesjonelt samarbeid. 72,5\% sier at casen om pasienten Emma i stor grad motiverte til å lære om tverrprofesjonelt samarbeid, og 96,1\% av studentene var meget positive til å benytte videocase som verktøy for læring. En student sier: "Casen om Emma gjorde behovet for mange innfallsvinkler tydelig. Sett $\mathrm{i}$ kombinasjon med videoene, så har jeg nå et bedre grunnlag for å vurdere cases i fremtiden, og er motivert til å lytte til alle profesjoners perspektiver på hva som er viktig fra case til case.» Flere studenter sier at casen 
om Emma var lærerik fordi den ga en praktisk tilnærming til det å jobbe tverrprofesjonelt, den opplevdes mer personlig, og en reell pasientsituasjon ga god hjelp til bedre forståelse. Ifølge Susan McLean (2016) vil læringsprosessen ved casebasert læring støtte dybdelæring, der studenten beveger seg fra å reprodusere kunnskap til å søke mening gjennom å anvende kunnskap ved å vurdere situasjoner fra ulike perspektiver. Videocasen om Emma inkluderte mange nye problemstillinger og satte i gang ulike tankeprosesser hos studentene. De andre profesjonenes innspill og perspektiver gjennom diskusjonene bidro til å utvide studentenes forståelsesramme.

Casebasert læring trekkes fram som en god arbeidsform for å lære tverrprofesjonelt samarbeid, også på en digital arena. Videocasen om Emma motiverte til refleksjon over egen og andres profesjoner og roller og tydeliggjorde at tverrprofesjonell samarbeidslæring er avgjørende for å gi pasienten en helhetlig og god behandling. Videocasen skapte mest diskusjon og engasjerte til samarbeid. En student støtter dette og sier: «Følte at jeg lærte mest av case om Emma. Det var her det ble mest diskusjon.» Tverrprofesjonelle caser bidrar til å fremme kommunikasjon og engasjement mellom studenter (Thistlethwaite, 2012), og flere studenter sier at videocasen om Emma var motiverende, morsom, trigget til samarbeid og bidro til tydeliggjøring av andre profesjoners fokus. Studentene opplevde det som lærerikt at de ulike profesjonene presenterte sin vurdering av situasjonen. En student sier: «Det var lærerikt at summen av alle de forskjellige profesjoners fokus til sammen skapte et fullverdig behandlingsopplegg for pasienten.» Slik bidro de ulike profesjonenes kunnskap til en helhetlig tilnærming for å imøtekomme pasientens behov.

\section{Videreutvikling av case øker kompleksitet i læringen}

Ved utforming av en case bør en sikre at casen inneholder informasjon som er nyttig for alle profesjonene. En psykologistudent sier: «Synes at casen ble litt for lite utfordrende for min profesjon, spesielt når andre profesjoner hadde mer å bidra med.» En annen student sier: «Det var flere situasjoner der en vernepleier ikke var direkte tilknyttet.» Andre studenter etterlyser flere caser med flere tilleggsopplysninger og med økende kompleksitet i oppbyggingen. Videreutvikling av caser innebærer å trekke inn ulike profesjoner etter hvert i behandlingsoppfølgingen, med stigende kompleksitet og nivå på læringsutbyttene. Det å bli trygg på ens rolle og ansvar i egen profesjon og 
det å lære om andre profesjoners roller og ansvar er en kontinuerlig prosess. Noen profesjoner er mer aktuelle enn andre i starten av behandlingsforløpet, mens senere i forløpet vil det være naturlig å trekke inn andre profesjoner. Casebasert læring gir mulighet for at helsefagstudenter lærer å tenke og handle tverrprofesjonelt, som en grunnleggende kunnskap og ferdighet i alle faser av pasientens behandlingsforløp.

\section{Bevisstgjøring av egen og andres profesjoners roller og ansvar}

Det tverrprofesjonelle samarbeidet i grupper har bidratt til at studenten tar mer ansvar selv og bidrar til felles kunnskapsutvikling. En student sier: «Jeg har vært selvsentrert rundt min egen profesjon. Jeg lærte å ta litt mer plass, og faktisk si min mening om hvordan jeg så på casen.» En annen student sier at det var mest lærerikt «å få økt kunnskap om hver enkelt profesjon, og en forståelse for at alle profesjoner jobber mot et felles mål, men med ulike innfallsvinkler». Noen studenter opplevde også en bevisstgjøring om at profesjonene er totalt avhengige av hverandre for å oppnå den beste behandlingen for pasienten. En student sier at det var lærerikt «å få kunnskap om andre profesjoners kunnskap og arbeidsoppgaver og kunne ta i bruk egen kunnskap». Ved å identifisere problemstillinger, foreslå tiltak og diskutere behandlingsalternativer lærte de mye om hverandres profesjoner, roller og ansvar i tillegg til egen rolle og ansvar. Andre studenter trekker fram samarbeidet og diskusjonene i gruppa som mest lærerik. En student sier at det var mest lærerikt å delta i diskusjonene om den tverrprofesjonelle overflytningsrapporten, fordi: «Jeg lærte av andres kunnskaper.» Andre studenter trekker fram det å diskutere pasientforløpet med andre profesjoner, for eksempel «å sparre med medisinerstudenten» og delta i diskusjonen rundt caser, med viktige og sentrale momenter.

Studentenes deltakelse i Inter-Dig kan forstås som å delta i et kollektivt læringsmiljø der kunnskap konstrueres og bygges gjennom samhandling og i en kontekst, og der fagidentitet og faglig vekst styrkes gjennom individuelle læringsprosesser (Vygotsky, 1978; Engeström, 1987; Säljø, 2001). Noen studenter fremhevet som mest lærerikt at de fikk lese og høre om de ulike profesjonene, og hva de kunne bidra med, mens andre studenter trakk fram det å arbeide sammen i team og med utgangspunkt i caser gjøre vurderinger 
om pasientens problemstillinger fra flere synspunkter. Det er nettopp i relasjonen, samspillet og samhandlingen mellom studentene at læringsprosesser oppstår (Dysthe, 2001).

Studentene fikk erfare hva de andre profesjonene kan bidra med, lære om de ulike profesjonene og hvilken kunnskap de besitter. De fikk innsyn i profesjonenes refleksjoner og handlinger og begrunnelsene for disse. Studentene sier også at de lærte av hverandre. Læring skjer gjennom handlinger og erfaringer og gjennom å reflektere over handlingene i ettertid (Dewey, 1916). Oppgavene rundt casen om Emma engasjerer studentene til å dele kunnskaper og erfaringer og reflektere over disse, og nye spørsmål og perspektiver bringes inn, slik at teori og praksis knyttes sammen. Den ekspansive læringen involverer kollektive diskusjoner der det tverrprofesjonelle teamet forhandler over ulike perspektiver og konsepter (Engeström, 2000).

\section{Styrker refleksjon og faglig selvtillit}

Det å sette ord på egen kunnskap utfordret studentene til refleksjon. En student sier: «Det å sette ord på egen rolle, hva man kan bidra med og hvilken kunnskap man faktisk innehar viste seg å være mer utfordrende enn først antatt. Når man skal presentere det og forklare det for andre må man reflektere mer over det enn man ellers gjør.» Studenten får mer tid til refleksjon gjennom å delta i asynkrone skriftlige diskusjoner, og det bidrar til at en skriver mer gjennomtenkte og velformulerte innlegg (Dysthe, 2001). I den skriftlige, digitale kommunikasjonen i Inter-Dig deler også studentene erfaringer fra egen praksis. Bengt Molander (1996) refererer til Schön, som beskriver at refleksjonen innebærer å ta ett steg tilbake for å se og tenke over hva man har gjort, for å få perspektiv på situasjonen. En student utdyper hvordan de lærer av hverandre: «Å få vite mer om hva de andre profesjonene tenker i motsetning til å bare vite hva de gjør, lærte jeg litt mer om hvorfor de gjør det. Følte da at vi lærte av hverandre.» De digitale diskusjonene ga studentene mer tid til å resonnere, analysere og reflektere rundt casen om Emma, og det bidro til å synliggjøre fellesnevnere og ulikheter i vurderingene som ble gjort. "Jeg har fått mer faglig selvtillit, noe som har vært utrolig motiverende midt i bachelorutdanningen", sier en student. Andre studenter sier de opplevde læring i eget fag som veldig god, og at de har lært å diskutere, resonnere og vurdere. Gjennom å samarbeide med andre profesjoner måtte 
de forklare hva, hvorfor og hvordan de tenker for å utføre sin egen kompetanse. For mange studenter har den største oppdagelsen vært å forstå hvor viktig det tverrprofesjonelle samarbeidet er, bli bevisst på hvor mange profesjoner som faktisk samarbeider om samme pasient, og en bevisstgjøring om hvor lite kunnskap studentene hadde om hverandres profesjoner. Andre studenter sier de opplevde en bevisstgjøring om at de kunne mer enn de trodde. De har lært å stole på egen kunnskap, de er blitt flinkere til å stille spørsmål, og de er blitt tryggere på eget fagområde.

\section{Hvordan samarbeidet studentene tverrprofesjonelt ved hjelp av digitale verktøy?}

Studentene gir ulike tilbakemeldinger på hvordan de opplevde å samarbeide ved hjelp av digitale verktøy i Canvas, som var diskusjonsforum, og samskriving via Office 365. Studentene møttes i tverrprofesjonelle grupper på en digital arena uten at de kjente hverandre på forhånd. De fleste var ukjente med bruken av verktøyene i Canvas og kjente lite til tverrprofesjonell samarbeidslæring. Hvilken rolle inntok studentene i den tverrprofesjonelle gruppa, og hvem tok ledelsen? Hvordan foregikk meningsutvekslingen, og hvordan forhandlet de seg fram til en felles forståelse?

Inter-Dig ble utviklet med en fleksibilitet slik at studentene selv kunne ta ansvar for å beslutte når og hvordan de ville gjennomføre samarbeidet i de tverrprofesjonelle gruppene. Studentene i Inter-Dig inntok ulike roller og posisjoner og bygget relasjoner i det tverrprofesjonelle teamet. Studentene beskriver hvordan de løste dette på ulike måter. Noen studenter sier at det fungerte fint å samarbeide om casen. De diskuterte mye underveis, hadde en tett dialog og samarbeidet godt. Andre studenter stilte spørsmål og ga kommentarer til hverandre, først i samskrivingsdokumentet og etterpå i dialogene i diskusjonsforumet. Iversen og Hauksdottir (2020) sier at tillit til og respekt for andre profesjoners kompetanse og roller er viktig for at medlemmene i tverrprofesjonelle team skal kunne omstille seg og samhandle med ulike mennesker. Evne til kritisk refleksjon over egen og teamets funksjon har også betydning for samarbeidet i tverrprofesjonelle team. Anita Gudmundsen, Bente Norbye, Madeleine Abrandt Dahlgren og Aud Obstfelder (2018) undersøkte hvordan felles engasjement og forståelse rundt pasientfortellinger i praksis kan vokse fram i tverrprofesjonelle teammøter, der studentene selv får mulighet til å 
skape sitt eget tverrprofesjonelle samarbeid. Studentenes motivasjon for å lære tverrprofesjonelt samarbeid handlet om å få nok tid og rom til å lære og kommunisere. Studien viste hvordan studenter som former sitt eget samarbeid og lærer i grupper, utvikler komplekse fellesskap der tverrprofesjonelt samarbeid bidrar til å fremme deres egen naturlige læringsprosess (Gudmundsen, Norbye, Dahlgren \& Obstfelder, 2018). Studentene i Inter-Dig hadde fleksibilitet i tid og rom til å finne ulike tilnærminger og studieteknikker for hvordan de valgte å løse det digitale tverrprofesjonelle samarbeidet.

\section{Samarbeid $i$ diskusjonsforum}

Hvordan fant studentene fram til felles problemstillinger om Emma, og hvordan forhandlet de seg fram til felles tiltak og løsningsforslag? En student sier: «Vi brukte diskusjonsforumet innad i gruppa før vi gikk løs på fellesdokumentet. Der kom vi først med forslag, og deretter ble vi enige om hvordan vi skulle starte. I to oppgaver tok en student initiativ til å lage et forslag til hvordan vi skulle gå videre, og deretter gikk de andre inn og skrev inn. Så brukte vi diskusjonsforumet videre helt til alle var fornøyde med resultatet.» En annen student sier: «Alle presenterte sin vinkling av casen, og vi fikk på den måten utformet felles besvarelse.» I diskusjonsforumet foregikk diskusjonene med å identifisere problemstillinger, analysere disse og forhandle fram ulike tiltak, resonnere, vurdere og reflektere over disse, for så å komme fram til felles tiltak for pasienten som ble dokumentert i et felles samskrivingsdokument. Slik kan en forstå at studentene forhandlet seg fram til felles meninger. I meningsbrytingen og dialogen om Emmas utfordringer kommer studentene fram til ny innsikt og felles forståelse. Noen grupper diskuterte sammen i diskusjonsforumet ved å spille inn ulike forslag og ble enige om oppstarten før de gikk løs på fellesdokumentet med samskriving, mens andre grupper ventet på at noen skulle ta initiativ til å starte samarbeidet.

\section{Samarbeid om samskriving}

Om samskriving i Office 365 sier studentene at det fungerte stort sett fint, men noen hadde utfordringer i starten med å få det tekniske til å fungere, og en student fikk det ikke til. Flere studenter sier at dette var en fin læringsressurs 
for samarbeid. En student sier det slik: "Jeg er heller ikke vant til å samskrive i word online, men dette synes jeg var nyttig. Blir å ta det med meg videre i studiet.» En annen student sier: «Det gikk greit, men jeg følte at ikke alle var like delaktige.» Studentene diskuterte i forumet og skrev inne på samskrivingsdokumentet når flere studenter var til stede samtidig. "Vi stilte hverandre spørsmål i samskrivingsdokumentene. Lagde punkter hvor alle profesjonene skulle skrive inn deres bidrag. Vi skrev kommentarer til hverandre. Vi brukte punktene til å utfylle oppgavene», sier en student. Slik kommuniserte studentene med hverandre gjennom en skriftlig kommunikasjon. Men hva betydde fraværet av den muntlige kommunikasjonen i sanntid?

\section{Det digitale samarbeidet på godt og vondt}

Studentene har ulike meninger om hvordan diskusjonsforumet og samskrivingen egnet seg til å lære kommunikasjons- og samhandlingsferdigheter. Noen studenter sier det er fullt mulig å lære seg disse ferdighetene gjennom bruk av diskusjonsforum og samskriving på nett, mens andre savner diskusjoner i sanntid. Flere studenter sier at diskusjonsforumet fungerte godt til å diskutere og reflektere rundt casen om Emma. Mye av samarbeidet startet i diskusjonsforumet der de reflekterte sammen over det som var skrevet, de åpnet for nye innspill og diskuterte hvorfor de eventuelt skulle ta det med videre. En student sier: «Vi diskuterte mye sammen, og jeg likte at vi hadde så tett kommunikasjon sammen underveis.» Det ble derimot vanskelig å forholde seg til diskusjonene når flere samtaler foregikk samtidig, fordi det ble uoversiktlig og rotete.

\section{Fravaret av det fysiske møtet}

Studentene hadde ulike erfaringer med hvordan samarbeidet fungerte i gruppene. Kommunikasjon og samarbeid opplevdes utfordrende for noen fordi det var vanskelig å få kontakt med hverandre i Canvas. Noen studenter opplevde at det gikk tregt i starten med å komme i gang med gruppearbeidene, og dette var det ulike årsaker til. Kommunikasjonen ble vanskeliggjort fordi de logget seg inn til ulike tidspunkt. Noen startet med oppgavene med en gang, mens andre ventet. "Vi kunne med fordel ha avtalt tidspunkt for når 
de ulike oppgavene skulle diskuteres. Da tror jeg kommunikasjonen og samarbeidet hadde blitt bedre», sier en student. Andre studenter sier at samarbeidet var meget bra selv om de ikke møttes fysisk. For enkelte studenter har det vært utfordrende å jobbe digitalt uten å treffe hverandre fysisk. En student sier det slik: «Det har vært bra, men ikke optimalt. Det beste ville ha vært å ha noen fysiske møter i tillegg.» En ulempe ved asynkron kommunikasjon er at mindre tilstedeværelse kan føre til opplevelse av isolasjon og tap av motivasjonen (Dysthe, 2001). En student sier det slik: «Jeg vurderer fysisk samarbeid som mye bedre enn digitalt.» En annen student har en annen mening og sier: «Man kan samarbeide ved bruk av Canvas uten at man skal være til stede.» Flere studenter sier at de savner diskusjoner i sanntid fordi det lettere fører til feiltolking når en bare forholder seg til den skriftlige kommunikasjonen. Læringsprosesser oppstår både gjennom den skriftlige og muntlige kommunikasjonen, gjennom relasjonen, dialogen og samspillet med andre mennesker (Dysthe, 2001). Språket er vårt viktigste verktøy for læring (Vygotsky, 1987), og det er nettopp i dialogen, meningsutvekslingen og diskusjonen med andre at en virkelig lærer. Ved å tilrettelegge for en muntlig kommunikasjon får studenten mulighet til stille spontane spørsmål som gjør det lettere å delta aktivt i diskusjonen. For å møte studenten der han/hun er, kan en også tilrettelegge for ulike læringsaktiviteter med fokus på variasjon, kreativitet og nivå i utformingen (Biggs \& Tang, 2011).

Casen om Emma er utviklet på bakgrunn av en realistisk case, og det betyr at studentene ikke får møte pasienten ansikt til ansikt. Sykepleierstudenten etterlyser å møte pasienten i det virkelige liv for å kunne gjøre nødvendige observasjoner og bruke sine observasjonsferdigheter og sanser til fulle. En student sier: «Jeg synes denne læringsressursen var veldig spennende, men at den kunne ha vært enda bedre om man kunne møte sine samarbeidspartnere.» En annen student sier: «Digitalt samarbeid i sanntid kan være et godt substitutt til fysisk samarbeid, men kan ikke erstatte fysisk samarbeid på tvers av profesjonene, med forståelse av hverandres fag og fokus.»

\section{Betydningen av å møtes ansikt til ansikt}

Hvilken betydning har det fysiske møtet for å lære samarbeidsferdigheter? Min erfaring er at det digitale møtet aldri kan erstatte det fysiske møtet, men kan være et godt supplement. I det fysiske møtet er den nonverbale 
kommunikasjonen lettere å observere, fordi deltakerne har mulighet til å ta i bruk alle sansene. I det digitale møtet vil en kunne se og høre hverandre, men det er vanskeligere å observere kroppsspråket. I tillegg vil teknologien begrense muligheten for at en kan ta i bruk alle sanser. I utviklingen av Inter-Dig kunne en benyttet «blended learning» eller blanda læringsformer, der en kombinerer digital læring med fysiske samlinger, som kan optimalisere læringen ved å få det beste ut av begge arbeidsformer (Margaryan, Collis \& Cooke, 2004). For eksempel er omvendt undervisning, eller «flipped classroom», en studentaktiv læringsform der studentene arbeider både digitalt og i klasserommet. Ved omvendt klasserom flyttes den tradisjonelle undervisningen ut av klasserommet og erstattes med nettressurser, og klasserommet benyttes til studentaktive og sosiale aktiviteter (Abeysekera \& Dawson, 2015). Tilrettelegging av fysiske samlinger i tillegg til Inter-Dig kunne bidratt ytterligere til å styrke teamfølelse, samhørighet og studentenes samarbeids- og kommunikasjonsferdigheter. Både det skriftlige og muntlige språket har betydning for læring (Vygotsky, 1978). I utviklingen av Inter-Dig kunne en etablert fysiske refleksjonsgrupper i tillegg til Canvas, med veileder tilgjengelig for å støtte og veilede studentene. Jeg mener at dette kunne bidratt ytterligere til å styrke utviklingen av studentenes tverrprofesjonelle samarbeidsferdigheter.

Oppsummeringen så langt er at samarbeidet i de tverrprofesjonelle gruppene bidro til tverrprofesjonell vekst, og studentene lærte mye om samarbeid i tverrprofesjonelle grupper på en digital arena.

\section{Hvordan ble Inter-Dig organisert og gjennomført, og hva er forbedringspotensialet?}

Studentenes tilbakemeldinger er gode innspill for å forbedre brukergrensesnitt og navigering i læringsressursen. Når det gjelder oppbygging, struktur og navigering i Inter-Dig, oppsummerer flere studenter at det er for mye informasjon, læringsressursen er rotete, og det er vanskelig å finne fram. En student sier: «Idèen bak Inter-Dig er kjempegod! Jobb med brukergrensesnittet og gjør det mer ryddig og enkelt å navigere.» Andre studenter sier den fungerer godt og er oversiktlig og strukturert. "Jeg liker variasjon i læringen. Videoer, tekster, bilder, lydfiler, quizer. Noe individuelt arbeid, noe samarbeid. Det er 
bra!» sier en student. Studentene foreslår å lage enkle brukerveiledninger i form av korte videosnutter for å lære de ulike verktøyene i Canvas.

Digitalt samarbeid i Inter-Dig krever god organisering og koordinering når flere oppgaver bygger på hverandre og skal løses sammen i team. I InterDig er det totalt sju oppgaver, der to av disse er obligatoriske. Flere av studentene avtalte ikke med sine medstudenter om når de hadde tid til å arbeide med læringsressursen, noe som resulterte $\mathrm{i}$ at noen startet med gruppearbeidet med en gang, mens andre ventet. Mange studenter opplevde det frustrerende å måtte vente på de andre før de kunne starte eller fortsette med oppgavene. Flere studenter foreslår å sette tidsfrister på alle oppgavene slik at en kommer fortere i gang, og man slipper å vente på hverandre. Ved å anbefale studentene til å velge en gruppeleder straks teamarbeidet starter, kan de enes om gjennomføring og oppgavefordeling og dermed sikre raskere framdrift i gruppearbeidet. Utarbeiding av felles kjøreregler om deltakelse, fravær i gruppa, fordeling av roller og ansvar vil være nyttige tiltak. Et annet tiltak som kan vurderes, er å gjøre alle oppgavene obligatoriske.

\section{Styring kontra fleksibilitet}

Et annet aspekt å reflektere over er balansen mellom styring og fleksibilitet i Inter-Dig. En digital læringsressurs har fleksibilitet i den forstand at en kan studere når som helst og hvor som helst, uavhengig av tid og sted. Det betyr at studenten i stor grad kan bestemme når og hvor han/hun ønsker å studere, og kan tilpasse studier til fritid, jobb og privatliv. Fleksibiliteten i læringsressursen Inter-Dig ble trukket fram som en positiv opplevelse da en av studentene ble syk og måtte opereres akutt. Studenten hadde kontroll på det som skjedde underveis i oppgaveløsningen, og kunne bidra i gruppeprosessen og fullføre oppgaven fra sykesenga. Manglende struktur i organisering og ledelse av gruppearbeidet i Inter-Dig bidro til at noen studenter tok over ansvaret og gjennomførte oppgavene uten at alle var med. «Noen få dro oppgavene i land, mens andre var tilskuere. Tror dette kom av at vi ikke arbeidet samtidig», sier en student. En annen student sier: «Det gikk fint. Noen tok mer ansvar enn andre.» På den ene siden kan flere tidsfrister og obligatoriske innleveringer gjøre Inter-Dig mindre fleksibel og mer lærerstyrt. På den annen side er studentene gjensidig avhengige av hverandre for å kunne løse casen sammen, og det innebærer god organisering og ledelse i tillegg til felles kjøreregler. 


\section{En aktiv nettveileder og betydningen av studentens opplevelse av mestring}

I utprøvinga av Inter-Dig hadde studentene to nettveiledere tilgjengelig ved behov, en for faglig support og en for pedagogisk/teknisk support. Nettveilederne hadde ingen aktiv rolle underveis i diskusjonene, men var tilgjengelige for studentene ved behov. Anne Mette Bjørgen (2004) sier at en nettveileder bør være mye til stede i oppstarten av nettstudiet og først og fremst ivareta den organisatoriske og sosiale rollen. I Gilly Salmons 5-trinns modell for e-læring trekkes fram betydningen av å ivareta motivasjon og de sosiale og relasjonelle dimensjonene i starten av studiet for å skape trygghet og tillit (Salmon, 2000). I gjennomføringen av Inter-Dig etterlyser en student en seminarleder i diskusjonsforumet som kan stille spørsmål og styre diskusjonene: «Da kunne diskusjonen gå fra undertema til undertema etter hvert som gruppa avanserer.» Få studenter benyttet veileder til spørsmål underveis i gjennomføringen av Inter-Dig. Gjennom nettveileders reflekterende spørsmål, innspill og nye perspektiver kan diskusjonene heves til et høyere faglig nivå og bidra til dybdelæring (Fossland, 2015). Nettveileder kan også moderere diskusjonene ved å stille spørsmål, motivere studentene til å skrive innlegg og delta aktivt i diskusjonene.

\section{«The power of feedback is closing the gap»}

Dette sier John Hattie og Helen Timperley (2007) om effekten av å gi studenten tilbakemeldinger. En lærers tilbakemelding kan bidra til å lukke gapet mellom studentens aktuelle forståelse og ønsket måloppnåelse (Hattie \& Timperley, 2007). Nettveileder har en viktig rolle på en digital læringsarena, ikke minst med å gi studenten tilbakemeldinger underveis. Den formative vurderingen er kanskje en av de viktigste drivkreftene i undervisningen når den fungerer optimalt (Hattie \& Timperley, 2007). Formativ vurdering forstås som vurdering underveis og bidrar til å se læringsprosessen i utvikling framover, mens summativ vurdering ofte relateres til en slutteksamen og hva som er oppnådd av sluttkompetanse (Gamlem, 2015). Formativ vurdering er en prosess som anvendes både av lærere og studenter for å justere pågående undervisning og læring gjennom tilbakemeldinger (Hattie \& Timperley, 2007). Ved å legge til rette for flere tilbakemeldinger underveis i 
utprøvingen av Inter-Dig kunne dette bidratt til å styrke studentenes motivasjon for å lære tverrprofesjonelt samarbeid. En tilbakemelding kan fungere som et hjelpemiddel for å oppnå intendert læringsutbytte og optimalt tilpasset undervisning. Hattie og Timperley (2007, s. 90) sier at: "The power of feedback is closing the gap between where students are and where they are aiming.» En nettveileder i Inter-Dig kunne veiledet studentene ved å gjøre læringsutbyttene enda mer konkrete og hjulpet dem med utforming av egne læringsmål for å vise veien til måloppnåelse.

Ifølge Siv Måseidvåg Gamlen (2015) framhever Lev Vygotskij den aktive rollen til læreren som gjennom veiledning engasjerer studentene ut ifra spørsmålene som blir stilt. Studentene i de tverrprofesjonelle gruppene i InterDig representerte ulike studieår og var på ulike nivå i sin utdanning, som var et godt utgangspunkt for å lære av hverandre. I en studie av Andreassen og Holmsen (2018) ble lærerens involvering og rolle trukket fram som viktig for å motivere studentene til diskusjoner gjennom å identifisere og se sammenhenger mellom teori og praksis. Studentene i Inter-Dig representerte ulike studieår i sine utdanninger, og dermed ulike kompetanser, som var et godt utgangspunkt for å lære av hverandre. Yrjö Engeström og Annalisa Sannino (2010) beskriver ekspansiv læring som å bevege seg inn i den nærmeste utviklingssonen (the zone of proximal development), der læringen skjer i et fellesskap mellom deltakerne gjennom felles aktiviteter med diskusjoner, forhandlinger om ulike prioriteringer og valg, som til slutt konstruerer et nytt «objekt» som implementeres i praksis. Objektet skaper selve meningen, målet og hensikten med et kollektivt aktivitetssystem og har betydning for at endringsprosesser igangsettes (Engeström \& Sannino, 2010). Tilbakemeldinger fra en medstudent og/eller en nettveileder kan gi studenten videre retning for læring med utgangspunkt i hva studenten mestrer alene. I gjennomføringen av Inter-Dig hadde vi minimale lærerressurser tilgjengelig for å veilede studentene. Dette resulterte i at studentene fikk et begrenset veiledningstilbud i gjennomføringen.

\section{Avslutning}

Erfaringene fra studentenes deltakelse i Inter-Dig har gitt meg verdifull kunnskap. For å oppnå tverrprofesjonell samhandlingskompetanse skal studentene lære ulike kunnskapsområder: kommunikasjon, samhandling, rolleforståelse, verdier, refleksivitet og teamarbeid. Men hvilke arbeidsformer og 
læringsstrategier vil best støtte oppunder studentenes læring? Evalueringen viser til meget godt oppnådde læringsutbytter og støtter casebasert læring som en studentaktiviserende og kollektiv arbeidsform for å lære tverrprofesjonelt samarbeid. Digitale, asynkrone verktøy som diskusjonsforum og samskriving har fungert godt som kommunikasjonsverktøy, men for å optimalisere læringen bør en vurdere å ta i bruk flere verktøy for synkron kommunikasjon i tillegg til fysiske samlinger. Inter-Dig er et supplement for å øve samhandlingskompetanse i reelle situasjoner med en virtuell pasient til stede. Tverrprofesjonell samhandlingskompetanse utvikles i relasjonen, samhandlingen og kommunikasjonen mellom mennesker, og da har det digitale møtet alene noen begrensinger. Men digital kommunikasjon er et verdifullt supplement til det fysiske møtet. Casebasert læring kan i kombinasjon med arbeidsformen «flipped classroom» og en aktiv nettveileder bidra til å styrke studentens samhandlingskompetanse. Studentenes tilbakemeldinger tilsier at grensesnittet i Inter-Dig bør forbedres for å gjøre navigeringen enklere, brukerveiledninger bør utvikles til samarbeidsverktøyene, og det bør utarbeides felles kjøreregler for organiseringen av det tverrprofesjonelle samarbeidet i grupper. Til tross for dette framstår Inter-Dig som en nyttig digital læringsressurs i utvikling av studentenes samhandlingskompetanse.

Erfaringene fra dette prosjektet er at digital læring gir uanede muligheter, og at en alltid bør gjøre pedagogiske vurderinger om hvilken sluttkompetanse som skal oppnås, hva som er faginnholdets egenart, og hvem som er målgruppa ved valg av digitale verktøy og arbeidsformer. Digital læring stiller også krav til digital kompetanse hos både undervisere og studenter for at Inter-Dig skal bidra til å styrke studentenes læring. Når teknologi anvendes i undervisning, bør en ta høyde for å involvere studentene, utøve digital dømmekraft og sørge for at teknologien benyttes kun der det er formålstjenlig. Vi lar oss lett fascinere av teknologiens uendelige mulighetsrom og glemmer ofte at det er studentens læring som skal være i fokus. Den digitale kompetansen hos lærere og studenter innebærer blant annet å ha ferdigheter i bruken av digitale verktøy, dette gjelder både i produksjon av læringsressursen og i gjennomføringen. Studentenes stemme må alltid tas med inn i de ulike prosessene. For framtiden bør forskning vies spesielt til studentenes læring: Hvordan lærer de, hvilke læringsstrategier bør benyttes som fremmer læring, og hvordan kan studentene bidra som aktive innholdsprodusenter for å styrke undervisningskvalitet i høyere utdanning? Teknologien vil fortsatt utfordre oss på hvordan vi organiserer utdanning i framtiden, og da bør en vite hvilke læringsstrategier som fremmer læring, der både lærere og studenter er aktive deltakere og er med på å legge premissene. 


\section{Referanser}

Abeysekera, L. \& Dawson, P. (2015). Motivation and cognitive load in the flipped classroom: definition, rationale and a call for research: HERSDA Higher Education Research \& Development. ISSN: 0729-4360 (Print), s. 1-14. DOI: https://doi.org/10.1080/07294360.2014.934336

Andreassen, H. M. \& Holmsen, T. L. (2018). Case-based learning in nursing education. Nordisk sygeplejeforskning, 3, s. 219-229.

DOI: https://doi.org/10.18261/issn.1892-2686-2018-03-05

Biggs, J. \& Tang, C. (2011). Teaching for quality Learning at University. London: The Society for Research into Higher Education \& Open University Press.

Bjørgen, A. M. (2004). Hvordan legge til rette for dialog og samarbeid i nettbaserte læringsmiljø? Evaluering av studiet "Fleksibel og nettstøttet læring”. Et studium for lærere i Buskerud fylke. Høgskolen i Lillehammer: Senter for livslang læring. Dewey, J. (1916). Democracy and Education. United States: Kessinger Publishing`s Rare Reprints.

Dysthe, O. (red). (2001). Dialog, samspel og laring. Oslo: Abstrakt Forlag AS.

Engeström, Y. (1987). Learning by exspanding. An activity-theorethical approach to development research. Helsinki: Orienta-Konsultit Oy.

DOI: https://doi.org/10.1017/CBO9781139814744

Engeström, Y. (2000). Activity theory as a framework for analyzing and redesigning work. Ergonomics, 43 (7), s. 960-974.

DOI: https://doi.org/10.1080/001401300409143

Engeström, Y. \& Sannino, A. (2010). Studies of expansive learning: Foundings, findings and future challenges. Educational Research Review, 2010-01, (5)(1), s. 1-24. DOI: https://doi.org/10.1016/j.edurev.2009.12.002

Fossland. T. (2015). Digitale laringsformer i høyere utdanning. Oslo:

Universitetsforlaget.

Gamlem, S. M. (2015). Tilbakemelding for laring og utvikling. Oslo: Gyldendal Akademisk.

Garrison, D. \& Anderson, T. (2003). E-Learning in the 21th Century. A Framework for Research and Practice. London and New York: Routledge Falmer Taylor \& Francis Group. https://www.taylorfrancis.com/books/ mono/10.4324/9780203166093/learning-21st-century-randy-garrison 
Golaghaie, F., Asgari, S., Khosravi, S., Ebrahimimonfared, M., Mohtarami, A. \& Rafiei, F. (2019). Integrating case-based learning with collective reflection: outcomes of inter-professional continuing education. Reflective Practice, 20, 1. DOI: https://doi.org/10.1080/14623943.2018.1539660

Gudmundsen, A., Norbye, B., Dahlgren, M. A. \& Obstfelder, A. (2018).

Interprofessional student meetings in municipal health service-Mutural learning towards a Community of Practice in patient care. Journal of Interprofessional Care, 33, (1), s. 93-101.

DOI: https://doi.org/10.1080/13561820.2018.1515732

Graneheim, U. H. \& Lundman, B. (2004). Qualitative content analysis in nursing research: concepts, procedures and measures to achieve trustworthiness. Nurse Education Today, 24, (2), s. 105-112.

DOI: https://doi.org/10.1016/j.nedt.2003.10.001

Hattie, J. \& Timperley, H. (2007). The Power of Feedback. Review of Educational Research, 77, 1, s. 81-112. DOI: https://doi.org/10.3102/003465430298487

Hauksdottir, N. \& Iversen, A. (2020). Tverrprofesjonell samarbeidslæring på Helsefak. Rapport fra Fyrtårnprosjekt 2016-2019. Senter for helsefaglig pedagogisk utvikling. Det helsevitenskapelige fakultet. UiT Norges arktiske universitet.

Helse- og sosialdepartementet (2009). Samhandlingsreformen - Rett behandling - på rett sted - til rett tid (St.meld. nr. 47 (2008-2009). Oslo: Helse- og omsorgsdepartementet.

https://www.regjeringen.no/no/dokumenter/stmeld-nr-47-2008-2009-/id567201 Hentet 15.10.21.

Iversen, A. \& Hauksdottir, N. (red.). (2020). Tverrprofesjonell sambandling og teamarbeid. Kjernekompetanse for fremtidens helse- og velferdstjenester. Oslo: Gyldendal Forlag AS.

Kunnskapsdepartementet (2017). Forskrift om felles rammeplan for helse- og sosialfagutdanninger. <https://lovdata.no/dokument/SF/ forskrift/2017-09-06-1353>. Hentet 03.07.2020.

Kvale, S. (1997). Det kvalitative forskningsintervju. Oslo: Gyldendal Akademisk. Margaryan, A., Collis, B. \& Cooke, A. (2004). Activity-based blend: Human Resource Development International ed learning. ISSN: 1367-8868 (Print) 1469-8374 (Online) Journal homepage: <https://www.tandfonline.com/loi/rhrd20>. Hentet 03.07.2020. DOI: https://doi.org/10.1080/13678860410001676574 
McLean, S. (2016). Case based Learning and its Application in Medical and HealthCare Fields. A review in Worldwide Literature. Journal of Medical Education and Curricular Development, 3, JMECD.S20377.

DOI: https://doi.org/10.4137/JMECD.S20377

Molander, B. (1996). Kunskap i handling. Göteborg: Bokförlaget Daidalos AB.

Rolfe, G., Jasper, M. \& Freshwater, D. (2011). Critical reflection in practice. Generating knowledge for care. Palgrave Macmillan.

Säljø, R. (2001). Laring i praksis. Et sosiokulturelt perspektiv. Oslo: Cappelen Akademisk Forlag.

Salmon, G. (2000). E-moderating: The key to teaching and learning online. London: Kogan Page.

Meld. St.16 (2016-2017). Kultur for kvalitet i høyere utdanning. Regjeringen.no. https://www.regjeringen.no/no/dokumenter/meld.-st.-16-20162017/ id 2536007/sec2. Hentet 15.10.21.

UiT Norges arktiske universitet (2018). Strategi for det helsevitevitenskapelige fakultet (Helsefak). UiT mot 2022. https://uit.no/Content/388125/Strategi\%20 2014-2020\%20Helsefak.pdf. Hentet 15.10.21.

Utdanningsdirektoratet (2016). Digitale ferdigheter som grunnleggende ferdighet. Fra rammeverk for grunnleggende ferdigheter. https://www.udir.no/globalassets/ upload/larerplaner/lareplangrupper/rammeverk_grf_2012.pdf Hentet 15.10.21.

Thistlethwaite, J. (2012). Interprofessional education: a review of context, learning and the research agenda. Medical Education, 46, s. 58-70. Blackwell Publishing Ltd. DOI: https://doi.org/10.1111/j.1365-2923.2011.04143.x

Vygotsky, L. S. (1987). Mind in Society. The Development of Higher Psychological Processes. Cambridge, Massachusetts, London, England: Harvard University Press.

WHO (2010). Framework for action on interprofessional education and collaborative practice. Health Professions networks. Nursing and Midwifery. Human Resources for Health. https://www.who.int/publications/i/item/ framework-for-action-on-interprofessional-education-collaborative-practice. Hentet 15.10.21. 